\title{
Monitoring and Acceptance: Key Dimensions in Establishing Mindfulness
}

\author{
Bhikkhu Anālayo ${ }^{1}$
}

Accepted: 27 September 2021 / Published online: 19 October 2021

(c) The Author(s) 2021

\begin{abstract}
Monitoring and acceptance have been identified as key dimensions in mindfulness-based programs, with acceptance in particular being central to their beneficial potential. From an early Buddhist perspective, the notion of such acceptance could be enhanced by adding the qualification "wise." In other words, it is a wise form of acceptance that is indeed a key dimension of the type of cultivation of mindfulness which can be expected to lead to a diminishing of suffering and distress.
\end{abstract}

Keyword Acceptance; Monitoring; satipațthāna; Wisdom

A particularly fascinating dimension of contemporary research on mindfulness is the attempt to identify what precisely accounts for its remarkable efficacy and potential. In other words, what are the most central underlying mechanisms responsible for a range of salutary effects resulting from the cultivation of mindfulness?

An interesting approach in this connection takes the form of the monitor and acceptance theory (MAT). The basic idea is that "attention monitoring explains how mindfulness improves cognitive functioning outcomes," which needs to be combined with acceptance toward momentary experience "for reducing affective reactivity" and thereby "modifying one's relation to monitored experience" (Lindsay \& Creswell 2017, p. 48). In this context, the term "acceptance" stands for "an objective, non-reactive lens through which to view momentary experience" (p. 49). The expression "attention monitoring" in turn refers to an "ongoing awareness of present-moment sensory and perceptual experiences" (p. 50). The collaboration of these two dimensions then takes the following form: "attention monitoring practices provide a scaffold for noticing moment-to-moment experience, which are viewed through an accepting lens" (p. 51). In sum (p. 57):

Practice in monitoring one's experiences trains attentional processes and enhances these experiences as they occur in the present moment. Acceptance modi-

\section{Bhikkhu Anālayo}

1 Barre Center for Buddhist Studies, 149 Lockwood Road, Barre, MA 01005, USA fies the way an individual relates to the content of monitored experience, tempering affective reactivity to produce a variety of beneficial outcomes across affective and physical health domains.

As highlighted by Lindsay and Creswell (2019), out of these two dimensions of mindfulness practices, the key quality responsible for positive outcomes is acceptance. In fact, just paying attention to what is painful may simply increase the intensity of the pain (although this is not always the case; see Wang et al. 2019, p. 1357). Simione et al. (2021, p. 1407) emphasized that "the beneficial effects of mindfulness on affective outcomes depend on acceptance alone." Nevertheless, "if too little attention is given to one's experiences (corresponding to low observing), one's nonjudging tendency does not exert its positive benefits." As already noted by Krafft et al. $(2017,20)$, "at least moderate mindful awareness is needed for acceptance to be beneficial."

\section{A Cowherd's Mindfulness}

The stimulating observations quoted above invite an exploration of relevant indications from early Buddhist sources, in an attempt at providing an additional perspective. Here, it needs to be noted first of all that the relevant textual sources do not explicitly tackle this topic. Hence, what follows is an attempt to draw out some of the relevant implications, which therefore is only a subjective interpretation of the material and should clearly be seen as limited in this respect. 
A first distinction to be drawn here is between mindfulness and the establishments of mindfulness (satipatthāna, smrtyupasthāna, 念處, dran pa nye bar gzhag pa). Only the latter is associated with definite beneficial outcomes, for which reason the cultivation of the four establishments of mindfulness is of direct relevance to the present exploration. Mindfulness as such, at least in early Buddhist thought, could even be unwholesome (Anālayo 2018b). That is, early Buddhist soteriology does not invariably commend unqualified mindfulness as such, but much rather advocates its cultivation in the form of four establishments, aimed at liberating the mind from defilements.

At times, mindfulness can feature in an early Buddhist text without having any overt relationship to being either wholesome or unwholesome (Anālayo 2020b). An example occurs in a simile employed to illustrate two different situations, which are when unwholesome thoughts occur in the mind or else when they are, at least temporarily, absent. The first of these two situations compares to a cowherd who has to watch closely over the cows in order to prevent them from straying into the ripe crop. In the ancient setting, those who owned one or more cows were in need of someone to take them out daily for grazing. The cowherd's job would thus have been to collect various cows from their owners and then lead them to a place where they can eat grass. Since this place would not have been fenced, the cowherd was responsible for preventing the cows from straying into the cultivated fields, failing which would lead to punishment.

The cowherd's situation changes considerably once the crop has been harvested. As a result, there is no longer a danger of the cows causing damage, and the cowherd's task becomes consequently considerably less stressful. All that is now required is to be mindful of the presence of the cows (MN 19 and MĀ 102; see also Anālayo 2019a). Nevertheless, the cowherd still has a task, as the cows should not just be left to themselves; that is, the cowherd needs to continue monitoring them.

The introductory narration to another discourse features someone pretending to be a farmer who is searching for his oxen (SN 4.19 and SA 246). The pretense is based on the fact that in the ancient setting it must have been a wellknown fact that oxen were bound to amble off as soon as they are unattended, as a result of which they then have to be searched for. A Pāli discourse, parts of which appear to have been preserved in Gāndhārī manuscript fragments (AN 9.35 and Jantrasrisalai et al. 2016, p. 39), describes a cow getting into trouble due to hurriedly walking in search of grass in a mountainous area, as a result of which she is neither able to reach the place she wanted to reach nor to return safely to where she had been before.

Applied to the task of the cowherd, this suggests a need to continue observing what the cows are doing, being ready to intervene if a particular cow should be ambling off too far.
Such a situation calls for intervention, since in the evening the cowherd needs to return the cows to their owners. If one cow ambles off, the cowherd will eventually have to go in search of her, to make sure she does not get into a predicament like the one described above, which could even result in an accident and the cow getting hurt. Yet, by going in search of her, the cowherd would have to leave the rest of the group unattended, which may lead to more cows ambling off. Hence, there is continuous need to monitor the situation in order to ensure that the cows stay more or less together in the same area.

The cowherd simile describes a type of mindfulness that appears to be predominantly about monitoring. The idea of acceptances does not seem to be particularly relevant. In fact, if the cowherd were to become too accepting of what happens in the present moment, such as a particular cow ambling off, such acceptance risks having detrimental repercussions.

The cowherd's cultivation of mindfulness as such also does not have any evident relationship to progress on the path toward freedom from defilements. Of course, if a cowherd were to go forth to become a monastic, it could reasonably be expected that the former "training" in monitoring, if it can be called such, would facilitate cultivating the four establishments of mindfulness. But as long as the cowherd is just mindful of the cows, such practice does not seem to have a liberating potential in itself. For that to emerge, perhaps the cowherd would additionally need to attend to all aspects of the experience of monitoring the cows from the viewpoint of its impermanent nature. That is, some instructions in the development of insight would be required to turn the cowherd's job into a soteriologically significant activity.

In fact, a slight change of scenery could result in turning such a form of mindfulness into something unwholesome. Suppose the cowherd were to be turned into a hunter and the cows were to be changed into deer. The hunter may well be monitoring the deer in basically the same way as the cowherd the cows, but the intention behind such monitoring is substantially different: the purpose is to discern when a deer has come close enough to be within shooting range. This shift of intention from making a living in a harmless manner to doing the same in a way that inflicts harm would turn such mindfulness practice into something decidedly unwholesome.

Taking the same situation further, suppose the "mindfulness practitioner" is a soldier monitoring the enemy forces, again waiting for them to move within shooting range. The soldier may be quite non-judgmental about killing another human being. From an early Buddhist perspective, however, such a form of acceptance would have to be reckoned as decidedly unwholesome. In fact, the Buddha reportedly pointed out quite directly the detrimental repercussions of doing one's duty as a soldier, arguing that at the time of 
engaging in battle the mind is necessarily filled by a desire to harm, kill, and destroy (Anālayo 2009). Such types of intention are unquestionably unwholesome and therefore have detrimental repercussions.

In sum, the potential of mindfulness depends very much on the overall context within which it is deployed, which concerns in particular the ethical quality of the mind. Situated in an ethically reprehensible context, such as engaging in battle, mindfulness will have detrimental results. Cultivated in what appears to be an ethically neutral context, such as herding cows, does not yet ensure beneficial results beyond some incidental training in attention skills. What is required for mindfulness to unfold its potential benefits is an ethical setting that is of a wholesome type, by way of being combined in particular with the intention for non-harm. In addition, the instructions on the establishments of mindfulness point to several other qualities that enhance the liberating potential of mindfulness.

The following section explores relevant discourse passages, based on translations from the originals. Readers mainly interested in the practical implications of this exploration may prefer to skip this section and turn directly to the discussion of "Chief Dimensions of Mindfulness Practice."

\section{The Buddha's Discovery}

For the present purpose of providing an early Buddhist perspective on what appear to be crucial elements of mindfulness practice that yield beneficial outcomes, of particular relevance is a recurrent description of the four establishments of mindfulness. This description lists a set of mental qualities that surround and support mindfulness in the cultivation of each of its four establishments. These four establishments cover modes of contemplation that take as their object the body, feeling tones, mental states, and dharmas. The basics of cultivating mindfulness in this way were reportedly part of a reflection the Buddha had soon after his awakening:

This is the direct path for the purification of sentient beings, for the surmounting of sorrow and lamentation, for the disappearance of pain and discontent, for acquiring the [true] method, for the realization of Nirvana, namely, the four establishments of mindfulness. What are the four? One should dwell contemplating the body in regard to the body, diligent, clearly knowing, and mindful, free from greed and sadness with regard to the world. Or [one should dwell contemplating feeling tones] in regard to feeling tones ... or [one should dwell contemplating mind] in regard to mind ... or one should dwell con- templating dharmas in regard to dharmas, diligent, clearly knowing, and mindful, free from greed and sadness with regard to the world.

(SN 47.18: ekāyano ayam maggo sattānam visuddhiyā sokaparidevānam samatikkamāya dukkhadomanassānam atthañgamāya ñāyassa adhigamāya nibbānassa sacchikiriyāya, yad idạn cattāro satipațthānā. katame cattāro? kāye vā ... kāyānupassī vihareyya ātāp $\bar{\imath}$ sampajāno satimā, vineyya loke abhijjhādomanassam; vedanāsu vā ... citte $v \bar{a} \ldots$ dhammesu vā ... dhammānupass $\bar{\imath}$ vihareyya àtāpi sampajāno satimā, vineyya loke abhijjhādomanassam; here and below, references to a bhikkhu as the practitioner have been elided, in the understanding that these serve as an umbrella term for any practitioner; see Collett \& Anālayo 2014).

There is a one-vehicle path enabling the purification of sentient beings, the surmounting of sorrow and lamentation, the disappearance of pain and affliction, and the attainment of the truth according to the Dharma, namely the four establishments of mindfulness. What are the four? The establishment of mindfulness of the body [in regard to] the body ... feeling tones ... mind ... the establishment of mindfulness of dharmas [in regard to] dharmas.

(SĀ 1189: 有一乘道能淨眾生, 度諸憂悲, 滅除苦惱, 得真如法, 謂四念處. 何等爲四? 身身觀念處, 受, 心, 法法觀念處; on the expression rendered as “onevehicle" see the discussion in Nattier 2007, p. 189).

Alongside its clear soteriological orientation, the description given in the two passages above also offers indications relevant to a clinical employment of mindfulness. This takes the form of presenting the aim of such practice to be the surmounting of sorrow and lamentation, or else the disappearance of suffering and discontent or affliction. The two versions agree also in delineating the four areas for mindful contemplation and in presenting a key element of such practice by way of repeating the object taken, such as being mindful of the body in regard to the body. Only the first of the two versions, however, provides crucial information regarding the mental qualities that accompany mindfulness in this task. These are diligence, clear knowing, and freedom from reactivity by way of greed or sadness.

Although the second version translated above does not stipulate these qualities, another discourse in the same textual collection, the Samyukta-ägama, provides a definition of right mindfulness that covers these qualities as well. The discourse in question takes up the topic of right mindfulness, which serves as the seventh factor of the noble eightfold path, a fulfillment of which can take the form of 
cultivating the four establishments of mindfulness. The relevant definition proceeds in this way:

What is right mindfulness? Suppose one establishes mindfulness by contemplating the body [in regard to] the body internally, with diligent effort, right knowing, and right mindfulness, overcoming greed and sadness in the world. In the same way for feeling tones ... mind ... and one establishes mindfulness by contemplating dharmas [in regard to] dharmas, with diligent effort, right knowing, and right mindfulness, overcoming greed and sadness in the world.

(SĀ 622: 云何正念? 若 .... 內身身觀念住, 精勤方便, 正智, 正念, 調伏世間貪憂. 如是受, 心, 法法觀念住, 精勤方便, 正智, 正念, 調伏世間貪憂).

The Pāli parallel to the above discourse (SN 47.2) does not qualify such mindfulness to be of the "right" type. However, elsewhere a Pāli counterpart to the above definition of right mindfulness can be found (SN 45.8). The differences that have emerged thus far reflect the vagaries of oral transmission; in fact, even the discourse parallels to the Satipațthana-sutta, found in the Madhyama-āgama and the Ekottarika-ägama, do not have a proper counterpart to the stipulation of these qualities in the Pāli version (Anālayo 2013). Nevertheless, elsewhere in these two discourse collections indications can be found that highlight similar qualities:

Contemplate the body as a body internally, cultivating utmost energy, establishing right mindfulness and right knowing, properly conducting the mind so that it is free of covetousness and there is no dejection in the mind.

(MĀ 76: 觀內身如身, 行極精勤, 立正念, 正智, 善自 御心, 令離慳貪, 意無憂感).

Establish mindfulness by contemplating one's own body [in regard to] the body internally, oneself gathering that mind, discarding aimless perceptions and being without sorrow.

(EĀ 47.7: 內自觀身身意止, 自攝其心, 除去亂想, 無 有憂愁).

These two otherwise unrelated passages do not provide a precise match to the qualities mentioned above. Nevertheless, a range of other textual sources present the essentials of the establishments of mindfulness in terms of diligence, clear knowing, and freedom from reactivity by way of greed or sadness (Anālayo 2011, p. 76). In this way, although comparative study brings to light considerable variations and makes it difficult to take a firm stance on the early Buddhist consensus on the matter, it nevertheless does seem reasonable to take these indications as a starting point for further exploration.

\section{Chief Dimensions of Mindfulness Practice}

Four chief dimensions of the cultivation of the four establishments of mindfulness can in this way be identified. One of these concerns the circumstance that the object of mindful contemplation is mentioned twice. In the case of the body, for example, one should contemplate the body as a body, or the body in regard to the body. Another two dimensions are diligence and clear or right knowing. A fourth dimension is the absence of reactivity by way of desire and aversion. These four dimensions can conveniently be examined one after the other.

The Pāli commentarial tradition offers a series of explanations of the meaning believed to underlie the repetition of the meditative object (Ps I 242), not all of which are necessarily compelling (Anālayo 2003, p. $34)$. The instruction itself clearly conveys a sense of emphasis, which could be taken to convey the notion of remaining present with the body, etc., as it manifests right in the present moment. Such an interpretation would enable relating this dimension of the establishments of mindfulness to the cultivation of bare awareness (Anālayo 2018a, 2019b). Instructions in such bare awareness also employ repetition to convey an emphasis on remaining present with what is experienced. This takes the following form:

You should train yourself thus: In what is seen there will be just what is seen, in what is heard there will be just what is heard, in what is sensed there will be just what is sensed, in what is cognized there will be just what is cognized.

(Ud 1.10: te evam sikkhitabbam: ditthe dițhamattam

bhavissati, sute sutamattam bhavissati, mute mutamattam bhavissati, viñ̃̃āte viñ̃̃ãtamattam bhavissati ti).

Although the establishments of mindfulness are not in themselves a form of bare awareness, as they clearly involve the employment of concepts and even reflection, a commonality between their cultivation and bare awareness would be the idea of being present with what is, without proliferation. Expressed in a different way, the main idea would be to invite a mental pausing in order to remain just with what is actually taking place, rather than immediately getting carried away by various associations related to the present moment's experience. This non-proliferative aspect of mindfulness can have a broad range of applications, from the most mundane activity all the way up to deep insight meditation on the brink of realization. The basic idea could be exemplified with an exercise that forms part of the MBSR curriculum, which takes the form of mindfully eating a raisin. This serves as a skillful means to help practitioners realize the 
potential of being fully present during the act of actually and fully tasting something they have eaten many times before.

This first dimension of such non-proliferative receptivity has a complement in the fourth, which concerns remaining free from greed and sadness with regard to what arises in experience (or overcoming them). This can conveniently be taken to form a counterpart to the notion of being non-judgmental or equanimous (Anālayo 2021). Whereas the emphasis on remaining present with what manifests in the moment can be related predominantly to perception, that is, to the way incoming data is received in the mind, the idea of being non-judgmental or equanimous can be related to how the mind reacts to this data. Needless to say, these two dimensions closely interrelate, as any reactivity will in turn color the way things are being experienced. Thus, the above suggestion is not meant to set these two dimensions totally apart but only to bring out nuances in emphasis in regard to the deployment of mindfulness in the form of open receptivity and non-reactivity.

The quality of diligence in turn reflects the need to engage in actual practice, repeatedly and over long periods. Although contemporary research at times finds results even after very short periods of mindfulness practice, the lasting and deep transformation that this quality is able to effect requires wholehearted and sustained dedication to its cultivation. It takes time, and usually much more than generally expected. Hence, there is a need for diligent dedication that does not waver with the inevitable ups and downs of life and practice.

In fact, the terminology employed in the original text is fairly strong, conveying the sense of an all-out endeavor. Such endeavor needs to be of a balanced type, as excessive striving can become just as detrimental as excessive laxity. A convenient simile provided in the discourses illustrates the situation with the example of a stringed musical instrument (AN 6.55; for a survey of parallels see Anālayo 2019c, p. 163). If the strings are too tight, it will not be possible to play music, and the same holds when the strings are too loose.

A quality that still remains to be considered is "clear knowing" or "right knowing," sometimes also rendered as "clear comprehension." The "knowing" part in this term can be related to a recurrent injunction made in the Satipatthāna-sutta in relation to a range of contemplations, which require that the practitioner "knows" (pājānati) what is being contemplated. The chief implication of clear knowing in turn appears to be the fostering of clarity in recognition and understanding (Anālayo 2020a). Within the context of the establishments of mindfulness, it appears to be in particular this quality which furnishes the foundation for the arising of liberating wisdom. In early Buddhist thought, the contribution to be made by wisdom is crucial for progress to increasing levels of freedom from sorrow and lamentation, or else from suffering and discontent or affliction.

In sum, then, a cultivation of the establishments of mindfulness, being the setting within which the potential of mindfulness to produce beneficial effects emerges prominently, brings out the dimensions of non-proliferative receptivity together with the absence of reactivity, which combines with the need for continuity achieved through diligence and the clarity of wise understanding.

From this viewpoint, then, the notion of acceptance as a crucial ingredient for beneficial outcomes across affective and physical health domains could be further enhanced by adding the qualification "wise." In other words, just as "monitoring" actually stands for "attention monitoring," in the same way "acceptance" could be understood to imply "wise acceptance." This is in a way commonsensical, since just acceptance as such will not necessarily have beneficial effects. It is in this respect similar to the mere deployment of attention or monitoring, which on its own can make the situation even worse. The same holds for acceptance, should this be of the unwise type.

The cultivation of wise types of acceptance could at times take the form of directing attention to impermanence. Such type of acceptance would stand for "an attitude of openness and receptivity towards the transient nature of all phenomena. It involves a sense of ease and calmness in the face of the impermanent nature of phenomena" (Fernández-Campos et al. 2021, p. 1542). Inculcating an understanding of impermanence in this way, based as it is on direct experience, can safely be assumed to offer a rather substantial contribution to the transformative potential of mindfulness.

Abbreviations AN: Ánguttara-nikāya; EĀ: Ekottarika-āgama (T 125); MĀ: Madhyama-āgama (T 26); MN: Majjhima-nikāya; Ps: Papañcasūdan̄̄; SĀ: Samyukta-āgama (T 99); SN: Samyuttanikāya; Ud: Udāna

Funding Open Access funding enabled and organized by Projekt DEAL.

\section{Declarations}

Ethical Approval This article does not contain any studies performed by the author with human participants or animals.

Conflict of Interest The author declares no competing interests.

Open Access This article is licensed under a Creative Commons Attribution 4.0 International License, which permits use, sharing, adaptation, distribution and reproduction in any medium or format, as long as you give appropriate credit to the original author(s) and the source, provide a link to the Creative Commons licence, and indicate if changes were made. The images or other third party material in this article are included in the article's Creative Commons licence, unless indicated otherwise in a credit line to the material. If material is not included in the article's Creative Commons licence and your intended use is not 
permitted by statutory regulation or exceeds the permitted use, you will need to obtain permission directly from the copyright holder. To view a copy of this licence, visit http://creativecommons.org/licenses/by/4.0/.

\section{References}

Anālayo, Bh. (2003). Satipatțhāna, the direct path to realization. Cambridge: Windhorse Publications.

Anālayo, Bh. (2009). Yodhājīva Sutta. In W. G. Weeraratne (ed.), Encyclopaedia of Buddhism, volume 8 (pp. 798-799). Sri Lanka: Department of Buddhist Affairs.

Anālayo, Bh. (2011). A comparative study of the Majjhima-nikāya. Taipei: Dharma Drum Publishing Corporation.

Anālayo, Bh. (2013). Perspectives on satipațthāna. Cambridge: Windhorse Publications.

Anālayo, Bh. (2018a). The Bāhiya instruction and bare awareness. Indian International Journal of Buddhist Studies, 19, 1-19.

Anālayo, Bh. (2018b). Mindfulness constructs in early Buddhism and Theravāda: Another contribution to the memory debate. Mindfulness, 9(4), 1047-1051. https://doi.org/10.1007/ s12671-018-0967-3

Anālayo, Bh. (2019a). How mindfulness came to plunge into its objects. Mindfulness, 10(6), 1181-1185. https://doi.org/10.1007/ s12671-019-01152-4

Anālayo, Bh. (2019b). In the seen just the seen: Mindfulness and the construction of experience. Mindfulness, 10(1), 179-184. https:// doi.org/10.1007/s12671-018-1042-9

Anālayo, Bh. (2019c). On the six sense-spheres (3): A translation of Samyukta-āgama discourses 250 to 255. Satyābhisamaya, 90, $139-187$.

Anālayo, Bh. (2020a). Clear knowing and mindfulness. Mindfulness, 11(4), 862-871. https://doi.org/10.1007/s12671-019-01283-8

Anālayo, Bh. (2020b). Mindfulness in early Buddhism, characteristics and functions. Cambridge: Windhorse Publications.

Anālayo, Bh. (2021). Relating equanimity to mindfulness. Mindfulness. https://doi.org/10.1007/s12671-021-01671-z
Collett, A., \& Anālayo, Bh. (2014). Bhikkhave and bhikkhu as genderinclusive terminology in early Buddhist texts. Journal of Buddhist Ethics, 21, 760-797.

Fernández-Campos, S., Roca, P., \& Yaden, M. B. (2021). The impermanence awareness and acceptance scale. Mindfulness, 12(6), 1542-1554. https://doi.org/10.1007/s12671-021-01623-7

Jantrasrisalai, C., Lenz, T., Quian, L., \& Salomon, R. (2016). Fragments of an Ekottarikāgama manuscript in Gāndhārī. In J. Braarvig (ed.), Manuscripts in the Schøyen Collection, Buddhist Manuscripts (Vol. IV, pp. 1-122). Oslo: Hermes Publishing.

Krafft, J., Haeger, J., \& Levin, M. E. (2017). The interaction of mindful awareness and acceptance in couples satisfaction. Personality and Individual Differences, 113, 20-23. https://doi.org/10.1016/j. paid.2017.02.064

Lindsay, E. K., \& Creswell, J. D. (2017). Mechanisms of mindfulness training: Monitor and acceptance theory (MAT). Clinical Psychology Review, 51, 48-59. https://doi.org/10.1016/j.cpr.2016.10.011

Lindsay, E. K., \& Creswell, J. D. (2019). Mindfulness, acceptance, and emotion regulation: Perspectives from monitor and acceptance theory (MAT). Current Opinion in Psychology, Special Issue on Mindfulness, 28, 120-125. https://doi.org/10.1016/j.copsyc.2018. 12.004

Nattier, J. (2007). 'One vehicle' (一乘) in the Chinese Āgamas: New light on an old problem in Pāli. Annual Report of the International Research Institute for Advanced Buddhology at Soka University, 10, 181-200.

Simione, L., Raffone, A., \& Mirolli, M. (2021). Acceptance, and not its interaction with attention monitoring, increases psychological well-being: Testing the monitor and acceptance theory of mindfulness. Mindfulness, 12(6), 1398-1411. https://doi.org/10.1007/ s12671-021-01607-7

Wang, Y., Qi, Z., Hofmann, S. G., Si, M., Liu, X., \& Xu, W. (2019). Effect of acceptance versus attention on pain tolerance: Dissecting two components of mindfulness. Mindfulness, 10(7), 1352-1359. https://doi.org/10.1007/s12671-019-1091-8

Publisher's note Springer Nature remains neutral with regard to jurisdictional claims in published maps and institutional affiliations. 